\title{
Correlation between Mother's Behavior with Periodontal Status and Periodontal Treatment Needs in Children with Autism
}

\author{
Mega Moeharyono Puteri, Tania Saskianti and Ridha Rizki Ananda \\ Department of Pediatric Dentistry, Faculty of Dental Medicine, Universitas Airlangga, Surabaya, Indonesia
}

\begin{abstract}
Background. Autism is a neurological and developmental disorder. Children with autism have problems related to physical, psychological, and mental barriers that can hinder their ability to achieve optimal dental health status. Maintaining the dental health of children with autism is influenced by parents' teaching skills and habits. From previous study, there were about $17.4 \%$ children with autism in Saudi Arabia suffering from bleeding of the gingiva. Periodontal disease is often found in children with autism.
\end{abstract}

Objective. This study analyzes the relationship between mother's behavior with periodontal status and periodontal treatment needs of children with autism.

Methods. Analytical observational study with cross-sectional approach at AGCA Centre Surabaya with a total sample of 34 pairs of children with autism and their mothers. This study used the HU-DBI questionnaire which consisted of knowledge, attitude, and mother's action and oral examination of children with autism with the CPITN index.

Results. Of the children with autism, 55.8\% had healthy periodontal status. The knowledge, attitudes, and actions of mothers were high. Statistical results with Spearmen correlation test obtained a value of $p>0.05$ on aspects of knowledge, attitudes, and actions towards the CPITN index and periodontal treatment needs.

Conclusion. There was no significant correlation between the mother's behavior and the periodontal status and periodontal treatment needs of children with autism in managing their oral health.

Key Words: periodontal tissue, CPITN index, mother's behavior, autism

\section{INTRODUCTION}

Paper presented at the Joint Scientific Meeting in Special Care Dentistry, July 5, 2019, Amerta Room, 4th Floor, main campus of Universitas Airlangga, Surabaya, Indonesia.

Corresponding author: Mega Moeharyono Puteri Department of Pediatric Dentistry

Faculty of Dental Medicine

Universitas Airlangga

Jl. Mayjen. Prof. Dr. Moestopo No. 47 Surabaya 60132 - Indonesia

Email: mega-m-p@fkg.unair.ac.id
Autism can be defined as a neurological and developmental disorder that causes children to appear unable to relate to others, as if they live in their own world. ${ }^{1}$ The main characteristics of autism are related to problems of social interaction with others, communication disorders, repetitive behavior, and cognitive instability. ${ }^{2}$ The Centers for Disease Control and Prevention (CDC) in the United States in March 2013 reported that the prevalence of autism increased to 1:50 in the past year. When the number of births in Indonesia is 6 million per year, the number of children with autism in Indonesia increases by $0.15 \%$ or 6,900 children per year. ${ }^{3}$

In Saudi Arabia, 17.4\% of children with autism have been reported to have gingival bleeding. ${ }^{4}$ Meanwhile, Da Silva et al. state that oral health problems that are often found in children with autism are periodontal disease. ${ }^{5}$ 
Meanwhile, the dominant periodontal disease that is found in children and adolescents is gingivitis. ${ }^{6}$ Gingivitis is an inflammation that only involves gingival tissue with no loss of attachment or bone. ${ }^{7}$

Due to the problems of social interaction with others, communication disorders, and cognitive instability, children with autism cannot maintain their oral hygiene individually. ${ }^{8}$ Kalyoncu and Tanboga state that there was no difference between the prevalence of periodontal disease in children with autism so that the incidence of periodontal disease in these children is not much different from normal children. ${ }^{9}$ Another previous study also mentions that children with autism can maintain their good oral hygiene despite the limitations they have but their oral hygiene is based on family members healthy lifestyle habits. ${ }^{10}$

Behavior of children with autism in maintaining dental health such as tooth brushing habit and not being afraid to go to the dentist can be influenced by families/parents that teach skills and habits in their daily life. ${ }^{10}$ For this reason, oral health of children with autism is very dependent on their parents. ${ }^{11}$ The mother is the closest person to a child who always educates, teaches, and trains children's skills, especially in terms of maintaining oral hygiene. A child tends to take a behavior similar to his/her mother's behavior due to a process of imitation of a model that he/ she considers important. Mother's behavior regarding oral health can be used to predict the status or condition of the child's oral health. ${ }^{12}$

A few other studies describe the correlation between mother's behavior with periodontal status and periodontal treatment needs in children with autism. For this reason, the researchers wanted to examine the correlation between mother's behavior towards the periodontal status in children with autism and their periodontal treatment needs.

\section{MATERIALS AND METHODS}

This was an observational analytic study using a cross-sectional study design. The study was conducted at Special Education AGCA Centre Surabaya in September October 2018. The population in this study were all children diagnosed with autism in the Special Education AGCA Centre Surabaya, i.e., 34 students along with parents of children with autism according to the selection criteria for the research; each study participant had signed an informed consent form and the research protocol had been approved by an ethics committee. Criteria for selection of research subjects include: children diagnosed with autism, aged 3-14 years, in a healthy physical condition, accompanied by parent or caregiver, and were cooperative. The sampling technique used was total sampling.

Data collection was obtained from the results of the HU-DBI modification questionnaire (Hiroshima University - Dental Behavioral Inventory) regarding the behavior of maintaining oral health by mothers as parents of children with autism and examining the status of periodontal tissue of these children using the CPITN Index. ${ }^{13}$ Informed consent was given by mothers as respondents to be asked for research approval; respondents were interviewed directly by answering the questionnaire, and the status of periodontal of children with autism was examined using the CPITN Index. The results obtained were processed and presented in table form. Data analysis was performed using the Spearmen correlation test to analyze the relationship between the mother's behavior and the status of periodontal health and periodontal treatment needs in children with autism.

\section{RESULTS}

Data collected from questionnaire were in the form of the general characteristics of respondents and the relationship between mother's behavior and health of periodontal tissue and periodontal care needs of children with autism. In this study group, most of children with autism were at the age of 7-9 years in the mixed dentition stage at 50\%, followed by the age group $>10$ years at $26.47 \%$, and the age group 3-6 years at $23.5 \%$.

The educational background of the mothers with college education was $79.41 \%$, followed by the group of mothers with primary education (Elementary/Junior High/ Senior High School) which was $20.58 \%$. In this study, it was found that $47 \%$ of mothers did not have jobs, which was the majority of the total number of samples, followed by mothers who worked as private employees at 32.35\%, mothers who worked as civil employee at $8.8 \%$, and mothers with other jobs. Most mothers who had independent income above 3 million rupiahs consisted of $50 \%$ of the total sample; mothers who did not have independent income were 29.41\%; mothers with income range of 1 million - 3 million rupiahs were $17.64 \%$; and mothers who had independent income under 1 million rupiahs were $2.94 \%$.

Table 1 showed that most children with autism had a score of 0 or healthy periodontal tissue, i.e., 19 children (55.8\%). Then, there were 8 children with autism who experienced bleeding on probing (23.5\%), and children whose teeth had sub/supra gingival calculus on probing consisted of 7 (20.5\%). Table 2 showed that most children did not need periodontal treatment, i.e., 19 children (55.8\%). In addition, 8 children (23.5\%) needed an improvement in oral hygiene, while 7 children (20.5\%) needed dental health education and professional scaling. In this study, a HU-DBI questionnaire was used to measure the behavior of mothers in caring for and maintaining the health of these children's dental and oral health. Table 3 showed the distribution of mother's behavior in maintaining the children's dental and oral health. It is known that behavior is divided into three aspects, namely aspects of knowledge, attitudes, and actions. In the aspect of knowledge, it has the highest average value as compared to the other two aspects, namely all respondents had high scores or had average of $100 \%$. Furthermore, the 
Table 1. Periodontal status in children with autism with the CPITN index

\begin{tabular}{ccc} 
Score of CPITN & Frequency & Percentage (\%) \\
0 & 19 & 55.8 \\
1 & 8 & 23.5 \\
2 & 7 & 20.5 \\
3 & 0 & 0 \\
Total & 34 & 100 \\
\hline
\end{tabular}

Table 2. Periodontal treatment needs in children with autism with the CPITN index

\begin{tabular}{ccc} 
Treatment needs & Frequency & Percentage (\%) \\
0 & 19 & 55.8 \\
1 & 8 & 23.5 \\
2 & 7 & 20.5 \\
3 & 0 & 0 \\
Total & 34 & 100 \\
\hline
\end{tabular}

Table 3. Distribution of mother's behavior in maintaining children's dental and oral health

\begin{tabular}{ccc}
\hline Aspect & Frequency & Percentage (\%) \\
\hline Knowledge & 100 \\
High & 34 & 0 \\
Low & 0 & \\
\hline \multicolumn{3}{c}{ Attitude } \\
High & 31 & 91.1 \\
Low & 3 & 8.8 \\
\hline High & Action & 53 \\
Low & 18 & 47 \\
\hline
\end{tabular}

Table 4. Spearman correlation between mother's behavior and CPITN score

\begin{tabular}{ccccccccc} 
Score & \multicolumn{2}{c}{ Knowledge } & & \multicolumn{2}{c}{ Attitude } & & \multicolumn{2}{c}{ Action } \\
\cline { 2 - 3 } \cline { 7 - 8 } CPITN & Sig $(p)$ & $\mathbf{r}$ & & Sig $(p)$ & $\mathbf{r}$ & & Sig $(p)$ & $\mathbf{r}$ \\
Treatment & 0.5 & 0.10 & & 0.4 & -0.32 & & 0.7 & -0.54 \\
Needs & 0.5 & 0.10 & & 0.5 & -0.10 & & 0.6 & -0.85 \\
\hline
\end{tabular}

attitude aspect had a low value of $8.8 \%$ and a high value of 91.1\%. In addition, the aspect of action had low value of $47 \%$ and high value of $53 \%$.

Once the results of the study were analyzed, it was found that the significance value (p) was $>0.05$, so there was no correlation seen between the mother's behavior and the periodontal status (CPITN score), both from the aspects of knowledge, attitudes, and actions of the mothers and correlations with children's treatment needs (Table 4).

\section{DISCUSSION}

In this study, the number of children with autism examined was mostly male, i.e., 61.7\%, while females consisted of only $38.3 \%$. This is consistent with Nugraheni's research in 2012 stating that the prevalence of autism ranged from 1-2 per 1000 inhabitants and mostly found in men than women (4:1). ${ }^{14}$ This was related to differences in hormone production. From a study in person with autism ranging from 6-20 years old, it was found that men produce more testosterone hormone while women produce more estrogen hormones. Both hormones have the opposite function of a brain regulating gene called alpha retinoic acid related orphan receptor or RORA. The testosterone hormone can inhibit the performance of RORA while estrogen increases the work of RORA. If RORA's work is hampered, there will be brain coordination problems, for example, a gene should have the duty to protect nerve cells from stress and inflammation; meanwhile, if the performance is hampered, the cell cannot work properly. ${ }^{15}$

Periodontal status in children with autism examined using the CPITN index showed that $44 \%$ of children with autism had problems in their periodontal tissue. A total of 19 children from 34 total research subjects of children with autism had healthy periodontal tissue conditions, so that the periodontal treatment needs of these children in this study also amounted to a small number, i.e., $44 \%$, which required an increase in oral hygiene and professional scaling.

The results of this study showed that the majority of independent income of mothers was in the range of 1-3 million rupiahs, i.e., 24 people. This is in accordance with the research conducted by Duncan and Bonner in 2014, stating that a person's ability to pay for dental care for dental insurance coverage is directly related to the individual's income. High income individuals have a greater chance of receiving better dental care. ${ }^{16}$ Income received by mothers can be an addition to families to improve socio-economic status. Families with high socio-economic status will find it easier to obtain health services. Most of the samples in this study came from parents who had high socio-economic status, so they had a greater chance of getting health services in achieving better dental health. ${ }^{17}$

Furthermore, the profession of the mother is also influential. Of the total, $47 \%$ of the mothers of children with autism in this study did not have a job or were housewives, so they had more time to pay attention to maintaining the dental health of their children considering each child has limitations in maintaining his/her own dental health and is very dependent to parents especially the mother. This is because parents are role models for their children and are decision makers. Parental decisions are influenced by their attitudes which reflect children's oral health. If the mother's behavior regarding oral and dental health is good, her child's behavior will also be good. ${ }^{17}$

All respondents had a high level of knowledge, i.e., $100 \%$. This was consistent with the research conducted by Susi, Bachtiar and Azmi in 2012, stating that there was a relationship between the level of knowledge of parents about dental and oral health with the behavior of maintaining dental health in children. Majority of respondents, where 
$79.41 \%$ of them had college education, while the rest of the respondents who had primary education (SD/SMP/SMA) only consisted of $20.58 \% .^{18}$ Education can affect individual health status. The higher the level of education of a person, the easier it is to receive information. ${ }^{19}$ Someone who has a higher education will have better knowledge in maintaining and caring for his teeth. ${ }^{16}$

A total of $91.1 \%$ respondents had a good attitude in maintaining the dental health of their children. This was consistent with the research conducted by Oktarina in 2016, stating that there was a correlation between the level attitudes of parents about dental and oral health with the behavior of maintaining dental health of their children. ${ }^{19}$ Education will enhance information and influence the development of individual attitude towards newly introduced values. ${ }^{19}$ According to Notoatmodjo (2007), attitudes are the readiness of individuals to act according to their feelings and thoughts based on the values believed. So that attitude can be learned, instead of taken from birth; it is not settled, it can change. Attitude is the beginning of behavior that affects individual actions. This can be influenced by parents' initiative in preventing and promoting dental health problems. ${ }^{20}$ The higher the initiative of parents in terms of maintaining health, the greater the action that will be formed and the healthier the periodontal tissue of the child will be.

The results of this study in the aspect of action showed that $91.1 \%$ of respondents had good actions in maintaining the dental and oral health. This was consistent with the research conducted by Nurjannah in 2016 stating that there was a correlation between actions with the level of dental and oral hygiene. ${ }^{21}$ This is due to the level of full awareness of respondents regarding dental and oral health which has an impact on the hygiene status of their teeth and mouth. The higher the level of the mother's awareness, the more actions produced by the mother will be so that the child's optimal dental and oral health can be achieved.

After analyzing the data, this study showed that there was no significant relationship between the mother's behavior and the periodontal status and periodontal treatment needs in children with autism $(p>0.05)$ in aspects of knowledge, attitudes, and actions. This is consistent with the study of Oktarina, Tumaji and Roosihermiatie in 2016 stating that there was no significant relationship between mother's behavior (knowledge, attitudes, and actions) with children's oral and dental health. ${ }^{19}$ This can be caused by knowledge, attitudes, and actions which are not being the only factors that influence a person's behavior. In Oktarina et al's research, (2016), they noted Blum's theory which states that the health status of a person's mouth and society is influenced by four important factors, namely heredity, environment (physical and cultural), behavior, and health services. Mother's parenting also affects the behavior of mothers in caring for and maintaining the dental health of children. In this study, it was shown that the health of the periodontal tissues of children with autism tended to be healthy so that they did not require large maintenance needs. ${ }^{19}$

In this study, $44.1 \%$ of parents of children with autism used Indonesian's national health insurance and social security (BPJS). Besides mother's income and profession, health insurance also has a significant impact on dental care. The scope of dental insurance services is an important factor in deciding to seek dental care. The use of dental insurance can reduce or even eliminate the cost of dental and oral care which causes high demand for dental and oral health care. ${ }^{22}$ The scope of dental and oral services guaranteed by BPJS Health includes: extraction of primary teeth (topical, infiltration), permanent tooth extraction without complications, teeth scaling ( $1 \mathrm{x}$ a year), etc. ${ }^{23}$ Ease of access to dental health service facilities provided can encourage mothers to take their children to the dentist in terms of care for the child's teeth.

Special education of AGCA Centre located in Surabaya, East Java is a school for children who have special needs, such as children with autism, cerebral palsy, etc. AGCA Centre has an accreditation which is included in the superior schools and is located in elite high socioeconomic locations. The facilities and services provided are good for the costs required are not small so that not all children with autism can attend the AGCA Centre; only parents who have high socioeconomic status can send their children to AGCA. This can lead to uniformity or homogeneous data so that there is no big difference in the periodontal status of children with autism, so the majority of these children have a healthy periodontal tissue condition with little maintenance needs. In addition, environmental factors for children with autism can also affect the health of the periodontal tissue rather than only from the mother. Most of the time the child is used to going to the AGCA Centre daily. Information about maintaining the dental health of children can also come from schools, teachers, and the internet from the gadgets being played by children.

Oral and dental health of children with autism can be affected due to limited understanding of the importance of maintaining oral health, difficulties in communicating oral health needs, consumption of anticonvulsant drugs that affect gingival health, and fear of oral health procedures. In addition, children with autism tend to be hyperactive and have uncontrolled pulling of muscles. These children also have low levels of salivary secretions which can also lead to low oral hygiene. ${ }^{24}$

In addition, the difficulty in processing sensory stimuli is something that is found in many people with autism. Research by Cermak shows that the children's being more receptive to sensory responses is an important factor that influences their response to receive dental and oral care. ${ }^{24}$ Sensory stimuli that can be found in dental practice, such as bright neon lights from the dental chair, touches in and around the oral cavity in dental care actions, the atmosphere and smell of oral care products in the practice of dentists or hospitals, have the 
potential negative impact in these children, making it difficult for dentists to provide care. This can cause an increase in stress and anxiety of children with autism, and cause uncooperative behavior in receiving dental and oral care. ${ }^{25}$

Children with autism also tend to have self-injurious behaviors (SIB), which are located in the head-neck area, which can include head banging, face tapping, and gingival picking. In addition, they sometimes also have unusual parafunctional habits including bruxism, stretching their tongue forward, chewing things carelessly like gravel, cigarette butts, or pens. Children with autism also tend to have a preference for sweet and cariogenic foods. This can cause serious problems in the oral and dental health of children with autism. ${ }^{26}$ This is in contrast to the results obtained in this study that most children with autism have healthy periodontal tissue. This can be caused by the level of awareness from mothers of these children in maintaining their children's dental and oral health. School environment also supports children so that they can always maintain and care for the oral health of children. This study examined the mother's knowledge, attitudes, and actions to maintain their children's dental and oral health. Further study is necessary to examine the correlation between mothers' educational background and socio-economic status to obtain deeper information with Periodontal Status and Periodontal Treatment Needs in Autistic Children.

\section{CONCLUSION}

The results of research showed that there was no significant correlation between knowledge, attitudes, and actions of mothers in maintaining dental and oral health and the periodontal status and periodontal treatment needs in children with autism.

\section{Statement of Authorship}

All authors participated in data collection and analysis, and approved the final version submitted.

\section{Author Disclosure}

All authors declared no conflict of interest.

\section{Funding Source}

None.

\section{REFERENCES}

1. Jaber M. Dental caries experience, oral health status and treatment needs of dental patients with autism.J Appl Oral Sci. 2011;19(3):212-7.

2. Morales-Chávez MC. Oral health assessment of a group of children with autism disorder. J Clin Pediatr Dent. 2017; 41(2):147-9.

3. R. Arfiriana, and F. Dieny. Relationship to casein-free gluten-free diet score with autism behaviour score. Journal of Nutrition College. 2014;3(1): 34-42.

4. Murshid EZ. Diet, Oral Hygiene Practices and Dental Health in Autistic Children in Riyadh, Saudi Arabia. OHDM. 2014; 13(1):91-6.

5. da Silva SN, Gimenez T, Souza RC, Mello-Moura ACV, Raggio DP, Morimoto S, et al. Oral Health Status of Children and Young
Adults with Autism Spectrum Disorder: Systematic Review and Meta - Analysis. Int J Paediatr Dent. 2017; 27(5):388-98.

6. Varas F, Zillmann G, Munoz A, Hassi J, Yevenes I, Echeverria S, et al. Periodontal status and treatment needs of children from 6 to 8 years old in the Santiago Metropolitan Region of Chile. Rev Odonto Cienc. 2011; 26(1):10-5.

7. William V. Stenberg Jr., 6th ed. Periodontal Problems in Children and Adolescents. Pediatric Dentistry. 2019: 371-378.

8. Kumar S, Sharma J, Duraiswamy P, Kulkarni S. Determinants for oral hygiene and periodontal status among mentally disabled children and adolescents. J Indian Soc Pedod Prev Dent. 2009. 27(3):151-7.

9. Kalyoncu IÖ, Tanboga I. Oral health status of children with autistic spectrum disorder compared with non-authentic peers. Iran J Public Health. 2017; 46 (11):1591-3.

10. Nonong YH, Setiawan A, Dewi FD Navaneetha C. Oral health knowledge among parents of autistic child in Bandung-Indonesia. Dental Journal. 2014. 47(3):146-52.

11. Sengkey MM, Pangemanan DHC, Mintjelungan CN. Dental and oral hygiene status children with autism in Manado. Jurnal e-Gigi. 2015; 3(2):235-40.

12. Pintauli S. Analysis of behavior relationship of dental and oral health care on dental and oral health status of elementary and junior high school students in Medan. Jurnal Pendidikan dan Kebudayaan. 2010; 16(4):376-90.

13. Dagli RJ, Tadakamadla S, Dhanni C, Duraiswamy P, Kulkarni S. Self reported dental health attitude and behavior of dental students in India. J Oral Sci. 2008; 50(3):267-72.

14. Nugraheni SA. Revealing the Wilderness of Autism. Psychology Bulletin. 2012; 20(1): 9-17.

15. Deshinta R, Hardiani RS, Dewi EI. The Effect of Glenn Doman Method towards Autistic Social Interaction Ability in SLB-B and Autistic TPA. E-jurnal Pustaka Kesehatan. 2015; 3(1):66-73.

16. Duncan L, Bonner A. Effects of Income and Dental Insurance Coverage on Need for Dental Care in Canada. J Can Dent Assoc. 2014; 80:e6.

17. Bahaguna R, Jain A, Khan SA. Knowledge and attitudes of parents regarding child dental care in an Indian population. Asian J Oral Health Allied Sci. 2011; 1:9-12.

18. Susi BH, Azmi U. Relationship of parents' socio-economic status with caries in the child's primary teeth. Majalah Kedokteran Andalas. 2012; 36(1):96-105.

19. Oktarina, Tumaji, Roosihermiatie B. Correlation of mother factors and their kindergarten's oral health status in Kelurahan Kemayoran , Krembangan Sub district, Surabaya City. Bulletin Research in Health System. 2016; 19(4):226-35.

20. Kumar G, Dileep C L, Ahuja R. Oral health of preschool children in Dhanbad District, Jharkhand: A gander into the maternal behavior and practices. J Family Med Prim Care. 2016; 5(4):829-33.

21. Nurjannah. Relationship of Knowledge, Attitude, and Practice of Dental and Oral Health to Oral Hygiene Status in Students Junior High School (SMP)/MTs Pondok Pesantren Putri Ummul Mukminin. Essay. Faculty of Dentistry. Hasanuddin University; 2016. pp 1-64

22. Danial Z, Kalantar Motamedi MH, Mirhashemi S, Khoshmohabat H, Danial N. Universal Health Coverage and Oral Health. J Interdiscipl Med Dent Sci. 2016; 4:e106.

23. Social Insurance Administration Organization (BPJS). Practical Guide to Dental Services \& Dental Prosthesis for the Indonesia National Health Insurance Participants. BPJS Kesehatan. 2014; 9-11.

24. Blomqvist M, Bejerot S, Dahllöf G. A cross-sectional study on oral health and dental care in intellectually able adult with autism spectrum disorder. BMC Oral Health. 2015; 15:81.

25. Cermak SA, Duker LIS, Williams ME, Dawson ME, Lane CJ, Polido JC. Sensory Adapted Dental Environments to Enhance Oral Care for Children with Autism Spectrum Disorders: A Randomized Controlled Pilot Study. J Autism Dev Disord. 2015; 45(9):2876-88.

26. Naidoo M, Singh $S$. The oral health status of children with autism spectrum disorder in KwaZulu-Nata, South Africa. BMC Oral Health. 2018; 18:165. 